\title{
Ksenia Stanicka-Brzezicka
}

Herder-Institut für historische Ostmitteleuropaforschung

Institut der Leibniz Gemeinschaft

\section{"ZORGANIZOWANE I ZAANGAŻOWANE". MIESZCZAŃSKI RUCH KOBIECY I KOBIECY RUCH ARTYSTYCZNY W NIEMCZECH PRZEŁOMU XIX I XX WIEKU ZE SZCZEGÓLNYM UWZGLĘDNIENIEM STOWARZYSZENIA ARTYSTEK ŚLĄSKICH'}

"Organized and engaged". Bourgeoisie women movement and female artists movement in German at the turn of the $19^{\text {th }}$ and $20^{\text {th }}$ centuries with a particular regard to the Association of Silesian Women Artists

\begin{abstract}
The article presents the activity of women's artistic associations in Germany at the end of the $19^{\text {th }}$ and the beginning of the $20^{\text {th }}$ century. It focuses on the Silesian Women-Artists Association founded in Breslau (now Wrocław) in 1902. The association's goal was a protection of the members' interests, an organization of the collective exhibitions and a dispatch of artworks to bigger exhibitions. The positioning of the Breslau Association in the process of formation of the women's association culture in the bourgeois milieu, with the help of a sociological perspective and social class categories, is the main goal of the article. The applied method is justified not only by the references to the literature using or analyzing the same sociological perspective, but also by visible connections between the social context and the subject and style of the works of art. The city was the hob of the association activity and it enabled collective actions. The cultural capital and behavior patterns created in the bourgeois milieu stirred up an activity of women and women-artists, who started to associate. They left the private sphere which had been ascribed to them, and entered the public, which had been reserved for men. In 2002, Rita Huber-Sperl wrote „The associations, generally speaking, and women's associations in particular, are achievements of the bourgeoisie". The Breslau Association seems to affirm the quoted thesis.
\end{abstract}

Keywords: women's artistic associations, bourgeoisie, Silesia

Niniejszy tekst opiera się w części na badaniach autorki nad historią Stowarzyszenia Artystek Wrocławskich i twórczością jego członkiń, które opublikowane zostały w książce Artystki śląskie ok. 1880-1945, Wydawnictwo Adam Marszałek, Torun 2006 (rozdz. Działalność Stowarzyszenia Artystek Ślaskich [Vereinigung Schlesischer Künstlerinnen], s. 46-77), i jest próbą poszerzonej interpretacji działalności rzeczonego stowarzyszenia w odniesieniu do społeczno-klasowego kontekstu ruchu stowarzyszeniowego kobiet. 
„Nasza podróż była trochę męcząca. Przez cały czas myślałam o tym, co teraz nastąpi, i cieszyłam się strasznie. Mama była jednak przygnębiona i równocześnie zaniepokojona. Obawiała się, że jestem za młoda na życie w obcym, dużym mieście"2. Tak w 1905 roku opisała swoją podróż z Wrocławia do Drezna urodzona w dobrach

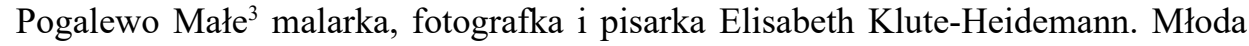
adeptka sztuki zmierzała do saksońskiej stolicy na studia, miasto bowiem zawsze stanowiło centrum wszelkich działań artystycznych oraz interakcji artystyczno-społecznych. Jednocześnie słowa te są świadectwem obaw i wątpliwości (ze strony matki), jakie towarzyszyły wkraczaniu kobiety na pole sztuki. Mogą one tu stanowić symboliczny wyraz ograniczeń i trudności, które pokonać musiały kobiety pragnące zajmować się profesjonalnie sztuką i które doprowadziły do uformowania się w drugiej połowie XIX i początkach XX wieku - w kontekście globalnej emancypacji kobiet - kobiecego ruchu artystycznego.

Jednym z głównych przejawów ruchu emancypacyjnego w ogóle było tworzenie różnego typu organizacji i stowarzyszeń. Literatura przedmiotu wyróżnia zasadniczo trzy rodzaje kobiecych ugrupowań tego czasu: ogólne, związane z działalnością dobroczynną i pielęgnacyjną oraz zawodowe (samopomocowe) ${ }^{4}$. Do tych ostatnich zalicza się przede wszystkim te związane z organizacją szkolnictwa, ale bez wątpienia należą do nich także stowarzyszenia artystek, o których będzie tu mowa nieco szerzej.

Kobiecy ruch emancypacyjny był niejednolity programowo i rozwijał się w kilku głównych nurtach, spośród których w Niemczech największe znaczenie miał umiarkowany, zabiegający przede wszystkim o poprawę edukacji kobiet i stworzenie im szerszych możliwości pracy zawodowej. Dla niniejszych rozważań istotny jest także formułowany wyraźnie w ostatnich latach pogląd, że ruch kobiecy zogniskowany był w środowisku mieszczańskim ${ }^{5}$. W roku 2000 w Hanowerze odbyła się konferencja „Organization, Partizipation und Interessen. Vereinskultur bürgerlicher Frauen im 19. Jahrhundert" (Organizacja, partycypacja i interes. Kultura stowarzyszeniowa kobiet pochodzenia mieszczańskiego w XIX wieku). Dwa lata później ukazała się publikacja pod redakcją Rity Huber-Sperl pod znamiennym tytułem Organisiert und engagiert. Vereinskultur bürgerlicher Frauen im 19. Jahrhundert in Westeuropa und den USA ${ }^{6}$, z której zaczerpnęłam częściowo tytuł artykułu.

2 E. Klute-Heidemann, Erinnerungen einer Kunstschülerin 1903 bis 1918. Breslau-Dresden - WeimarBerlin, Varlag am Schlössen, Kaufungen 1991, s. 46. Cytat ten (i następne) w thumaczeniu autorki.

3 Niem. Klein Pogul, obecnie powiat wołowski.

4 B. Greven-Aschoff, Die bürgerliche Frauenbewegung in Deutschland 1894-1933, Vandenhoeck \& Ruprecht, Göttingen 1981, s. 71 i n.

5 Zob. m.in. ibidem; R. Huber-Sperl, Bürgerliche Frauenvereine in Deutschland im ,, langen” 19. Jahrhundert - eine Überblickskizze (1780-1910), w: R. Huber-Sperl, K. Wolff (red.), Organisiert und engagiert. Vereinskultur bürgerlicher Frauen im 19. Jahrhundert in Westeuropa und den USA, Ulrike Helmer Verlag, Königstein 2002, s. 41-47; B. Kerchner, Beruf und Geschlecht. Frauenverbände in Deutschland 1848-1908, Vandenhoeck \& Ruprecht, Göttingen 1992.

6 Organisiert und engagiert..., op. cit. 
Ewentualne wątpliwości odnośnie do rozumienia terminu „bürgerlich” (który może znaczyć zarówno „mieszczański”, jak i „obywatelski”) wyjaśnia Barbara Greven-Aschoff ${ }^{7}$, odnosząc go jednoznacznie do pochodzenia społecznego angażujących się kobiet. Pojęcie Bürgertum - mieszczaństwo wymaga tu jednak pewnego doprecyzowania, ponieważ jako stan społeczny jest kategorią zarówno historyczną, jak i socjologiczną czy ekonomiczno-polityczną, podlegającą przemianom w czasie i zróżnicowaną terytorialnie. Wątek ten pojawił się ostatnio także w badaniach wrocławskiej historyczki Joanny Nowosielskiej-Sobel, poświęconych ruchowi ochrony stron ojczystych (Heimatschutz) ${ }^{8}$ w Niemczech, a szczególnie na Śląsku. Nowosielska pisze o XIX-wiecznym procesie „rozpadu tradycyjnych instytucji prawnych i społecznych obywateli miejskich, rozsadzania w wyniku procesów modernizacyjnych tradycyjnych struktur miejskich, powstawania w dobie rewolucji przemysłowej " «nowego mieszczaństwa»" i w efekcie wytworzeniu się , ,jakże ważnej z punktu widzenia narodzin samoświadomości narodowej formacji «mieszczaństwa wykształconego, inaczej formacyjnego» (Bildungsbürgertum)" ${ }^{\prime \prime}$, którego ogniwem spajającym było pojęcie kapitału kulturowego. To właśnie z tej grupy społecznej wywodziła się spora grupa zaangażowanych kobiet: , ,...] zasadniczo stowarzyszenia, a stowarzyszenia kobiece w szczególności, są osiągnięciem mieszczaństwa" - pisze we wstępie do wspomnianej już książki Huber-Sperl ${ }^{11}$. Już jednak bliższe spojrzenie na to szerokie zjawisko pozwala dostrzec wielość perspektyw i interpretacji, czasem nawet sprzeczności. Z jednej strony na przykład cała owa „kobieca kultura stowarzyszeniowa" (Frauen Vereinskultur) dotyczyła wąskiej grupy kobiet, krytycznie nastawionej i innowacyjnej elity. Z drugiej - zwłaszcza w odniesieniu do drugiej połowy XIX wieku, kiedy ruch kobiecy wyraźnie się ustabilizował - mówi się o pewnym rysie konserwatyzmu wynikającego z faktu, że kobiety nauczyły się oceniać granice tolerancji dla swoich działań w swoim środowisku i dostosowywały się do nich, co oznaczać mogło na przykład niebezpieczeństwo niepodejmowania bardziej radykalnych postulatów ${ }^{12}$.

Wiele rozbieżności widocznych jest też w opisywaniu roli innych warstw społecznych w ruchu kobiecym, zwłaszcza jeśli zawęzimy nasze zainteresowania do kręgów artystycznych. Tutaj należy jednak najpierw oddzielić metodologicznie zastosowanie pojęcia klasy społecznej do opisywania (kobiecego) ruchu stowarzysze-

B. Greven-Aschoff, op. cit., s. 13.

8 J. Nowosielska-Sobel, Od ziemi rodzinnej ku ojczyźnie ideologicznej. Ruch ochrony stron ojczystych (Heimatschutz) ze szczególnym uwzględnieniem Ślaska (1871-1933), Acta Universitatis Wratislaviensis, nr 3491, Wydawnictwo Uniwersytetu Wrocławskiego, Wrocław 2013, podrozdz. 2.1: Inteligencja mieszczańska (Bildungsbürgerturm) jako nośnik idei narodowych, s. 40-44.

9 Ibidem, s. 40.

10 Ibidem, s. 41.

11 R. Huber-Sperl, Bürgerliche Frauenvereine in Deutschland..., op. cit., s. 12; zob. także J. Kock, M. Frey (red.), Bürgerkultur und Mäzenatentum im 19. Jahrhundert, Fennei \& Walz, Berlin 1998.

12 R. Huber-Sperl, Bürgerliche Frauenvereine in Deutschland..., op. cit., s. 56. 
niowego (także artystycznego) i do studiów nad pochodzeniem społecznym artystów. Przynależność klasowa artystów była jedną z głównych kategorii marksistowskich socjologów sztuki. Później ów determinizm gospodarczy przezwyciężony został przez krytycznych teoretyków, takich jak Theodor W. Adorno ${ }^{13}$. Sami artyści tematyzowali czasami swoje pochodzenie w procesie mitologizacji. Dotyczy to jednak raczej środowisk awangardowych, nieco paradoksalnie, bo artyści reprezentujący nowoczesne kierunki żyli i tworzyli zwykle z dala od środowiska, z którego się wywodzili, niezależnie od tego, jakie ono było. Zupełnie inaczej niż wielcy mistrzowie: „Jeszcze impresjoniści żyli w dość mieszczańskim stylu” - pisze Klaus von Beyme ${ }^{14}$, i to zdaje się pasować dość dobrze także do większości artystycznych środowisk kobiecych, które skądinąd nierzadko uprawiały sztukę w kręgu postimpresjonizmu.

Pojęcie klasy społecznej w ramach gender studies - obok pojęcia rasy - zarysowało się wyraźnie zaraz po pierwszej fazie badań nad historią kobiet, koncentrując się na takich zagadnieniach, jak kobieca solidarność czy świadomość feministyczna. Metodologia ta utrzymuje się szczególnie w piśmiennictwie poświęconym historii społeczeństw ${ }^{15}$; historycy sztuki są tu zdecydowanie bardziej zdystansowani i skoncentrowani na dziele sztuki. Ponieważ jednak studia nad historią kobiecych stowarzyszeń artystyczno-zawodowych łączą te dwie perspektywy, stąd też próby zespojenia różnych podejść metodologicznych.

W literaturze poświęconej głównie sztuce kobiet pytanie o status społeczny pojawia się rzeczywiście dość często, zwłaszcza w konstelacji ze studiami nad formami organizowania się artystek. Spojrzenia na problematykę są różne, wiele zależy od dokładnego sformułowania problemu badawczego oraz dodatkowych czynników na przykład od tego, jakiego dokładnie okresu czy rodzaju sztuki dotyczy publikacja. Przyznać tu także wypada, że przygotowując książkę poświęconą śląskim artystkom, musiałam zadać pytanie o pochodzenie bohaterek:

Wiele artystek wywodziło się ze sfer ziemiańskich lub z rodzin mieszczańskich o różnym stopniu zamożności. Córkami kupców były Gertrud Staats (Adolfa Staats), Clara Sachs (Leopolda Moritza Sachsa) czy też Martha Giese-Breslau (Karla Schmooka). Inaczej natomiast niż

13 Th.W. Adorno, Ästhetische Theorie. Gesammelte Schriften, t. 7, Suhrkamp Verlag, Frankfurt 1973, 2003. Por. K. von Beyme, Das Zeitalter der Avangarden. Kunst und Gesellschaft 1905-1955, C.H. Beck, München 2005, s. 43.

14 K. von Beyme, op. cit., s. 44.

15 M.in. L. Barrow i in. (red.), Nichts als Unterdrückung? Geschlecht und Klasse in der englischen Sozialgeschichte, Westfälisches Dampfboot, Münster 1991; K.H. Schneider (red.), Geschlechtsrollen in der Geschichte aus polnischer und deutscher Sicht, seria: Politik und Geschichte, t. 5, red. A. von Saldern, H. Bley, H.H. Nolte, Historisches Seminar der Universität Hannover, LIT Verlag, Münster 2004 - tu zwłaszcza: G. Heuschen, Nützlich, gesellig, tugendsam - der bürgerliche Mann um 1800 (s. 159-178) i R. Huber-Sperl, ,, Wie ein Damoklesschwert”- Vereinsrecht und bürgerliche Frauenbewegung an der Wende zum 20. Jahrhundert (s. 195-214); J. Fischer, H. Delitz (red.), Die Architektur der Gesellschaft. Theorien für die Architektursoziologie, Transcript, Bielefeld 2009, tu zwłaszcza: S. Frank, ,"The beautiful source of suburban womanhood!”. Die Architektur der Gesellschaft aus Sicht der Gender Studies (s. 253-288). 
w biografiach „dawnych mistrzyń”, które były zazwyczaj córkami artystów, wykształconymi w ojcowskich pracowniach (na Śląsku przykładem jest córka Willmanna, Anna Elisabeth), $\mathrm{w}$ tym pierwszym profesjonalnym pokoleniu artystek jest tylko kilka przykładów pochodzenia z rodzin artystycznych: Leonore Bräuer była córką pejzażysty Albrechta Bräuera (1830-1897), Irmingard Aust - malarza Paula Austa (1866-1934), a Lotte Jaeckel - architekta Adolfa Jaeckela. Wśród nazwisk artystek pojawia się także kilka znanych śląskich rodów, jak np. Elise Ness von Eßenbeck, Alice von Maltzan, Maria hr. Matuschka i Helene Yorck-Kalcreuth ${ }^{16}$.

Dalej z tym zagadnieniem koresponduje kwestia stosunku rodziny do decyzji córek o poświęceniu się sztuce. Tutaj również pojawiła się kategoria klasy społecznej, uwaga zwrócona została na przypadki wyraźnego rodzinnego oporu właśnie w środowisku mieszczańskim:

Ojciec Renée Sintenis, prawnik, sprzeciwiał się uczęszczaniu córki do Kunstgewerbeschule w Berlinie i zmusił ją do podjęcia nauki zawodu sekretarki. Przyszła rzeźbiarka rzeczywiście opuściła szkołę artystyczną, ale kiedy ojciec zaczął nalegać, aby podjęła pracę, wyprowadziła się z domu i na własną rękę kontynuowała studia artystyczne. Wbrew mieszczańskim normom postąpiła również Margarete Haeffner-Moll: ,ppoczątek (...) wieku - 1902, niespełna dwudziestoletnia - odrzuca mieszczańską normalność, zostawia za sobą przymusy, opuszcza dom rodzicielski, aby zostać malarką. Niepojęte dla rodziców, ojciec - generał"17.

Jedną z głównych kwestii jest też zjawisko dyletantyzmu. Jego źródeł dopatruje się Brigitte Kerchner ${ }^{18}$ w ostatnim trzydziestoleciu XIX wieku, kiedy to w środowiskach mieszczańskich - obok zawodów nauczycielskich czy związanych z opieką socjalną i pielęgnacyjną - uprawianie sztuki, szczególnie malarstwa i literatury, stawało się odpowiednim zajęciem dla panien z tzw. dobrych domów. Jednak - jak pisze dalej Kerchner - uważano przy tym, aby uprawianie sztuki nie było źródłem dochodów, a jedynie przyjemnością. Jednocześnie zauważyć trzeba, że w czasie kiedy dostęp kobiet do akademii sztuk pięknych był zamknięty lub mocno ograniczony, funkcjonowanie w obrębie dyletantyzmu było niejako przymusowe i co gorsza - społecznie szeroko akceptowane. Prywatne szkoły artystyczne dla kobiet były kosztowne, a ich poziom często niezadowalający. To właśnie spowodowało sprzeciw aktywnych artystycznie kobiet i dało impuls do powstawania organizacji zrzeszających artystki, których jednym z głównych celów była walka o możliwości kształcenia artystycznego. Kerchner sytuuje powstawanie kobiecych stowarzyszeń artystycznych w procesie profesjonalizacji pracy kobiet. Definiuje je jako organizacje zawodowe (nie artystyczne) ${ }^{19}$. Tezę tę potwierdza później Cornelia Matz ${ }^{20}$. Dla niniejszego dyskursu

16 K. Stanicka-Brzezicka, Artystki śląskie ok. 1880-1945, op. cit., s. 227-228.

17 Ibidem, s. 228. Cytat w cytacie za: W. Filmer, 90 Jahre: Marg Moll, „Der Wegweiser” 26 (1974), z. 6/7, s. 17.

18 B. Kerchner, op. cit., s. 82 i n.

19 Ibidem, s. 131-132.

20 C. Matz, Die Organisationsgeschichte der Künstlerinnen in Deutschland von 1867 bis 1933, dysertacja doktorska, Fakultät für Kulturwissenschaften der Eberhard-Karls-Universität, Tübingen 2000, http://w210.ub.uni-tuebingen.de/dbt/volltexte/2001/417 (2002) (dostęp: 3.03.2016), passim. 
istotne jest jednak to, że wszystkie te procesy następowały w środowisku mieszczańskim. To tu wytworzył się kapitał kulturowy i wzorce zachowań, które poruszyły środowiska kobiece, w tym artystyczne, do aktywności, do wyjścia z przypisanej kobietom sfery prywatnej i wejścia w przestrzeń publiczną zarezerwowaną dotąd dla sprawujących władzę mężczyzn ${ }^{21}$, do stowarzyszania się.

Historia tworzenia stowarzyszeń artystek sięga mniej więcej połowy XIX wieku, kiedy to w 1857 roku w Anglii powstało Society of Female Artists. Dokładnie dziesięć lat później założony został Verein der Künstlerinnen und Kunstfreundinnen zu Berlin ${ }^{22}$.

Stowarzyszenie berlińskie było na terenie Niemiec prototypowe. Zajmowało się organizowaniem kształcenia i umożliwiania wystawiania, a także wsparciem finansowym czy ubezpieczeniami. Prowadziło własną szkołę, podobnie jak działające od 1882 roku stowarzyszenie monachijskie. W Karlsruhe prywatna szkoła dla adeptek malarstwa powstała w 1885 roku, a dopiero w 1893 roku doszło do założenia Malerinnenverein Karlsruhe. W Stuttgarcie w tym samym roku artystki zjednoczyły się w ramach Württembergischer Malerinnenverein, tworząc precedens pierwszej organizacji, która w nazwie odwołuje się do regionu. Do końca I wojny światowej powstały kolejne organizacje: w Bremie, Brunszwiku, Dreźnie, Düsseldorfie, Hamburgu, Kassel, Królewcu (Königsberg), Lipsku, Magdeburgu, Moguncji (1910, w 1917 rozszerzony, jako związek trzech miast, o Darmstadt i Frankfurt nad Menem), Rostocku, Pradze, Szwerinie; w tym samym okresie - w 1902 roku - także we Wrocławiu pod nazwą Stowarzyszenie Artystek Śląskich (Vereinigung Schlesischer Künstlerinnen $)^{23}$. Kolejne organizacje powstawały w nowej rzeczywistości Republiki Weimarskiej: na przykład w 1918 roku stowarzyszenie artystek Der Ring w Berlinie.

Stowarzyszenia zrzeszały bardzo różną liczbę członkiń - od kilkunastu do kilkuset. Niektóre, jak choćby w Berlinie, zrzeszały nie tylko artystki, ale i „,przyjaciółki sztuk" - najczęściej zamożne kobiety, mecenaski, znane osobistości. Zabieg taki miał na celu etablowanie się w towarzystwie i lokalnym środowisku artystycznym, szukanie kręgu odbiorców ${ }^{24}$. Najczęściej były to stowarzyszenia działające na terenie jednego miasta, ale z czasem rozszerzały one swoją działalność lub łączyły się $\mathrm{z}$ innymi organizacjami w struktury o zasięgu regionalnym (jak np. Bund badischer Künstlerinnen, 1912; Bund niederdeutscher Künstlerinnen, 1916), a następnie ponadregionalnym (jak Frauenkunstverband, 1913; Die Gemeinschaft Deutscher und

${ }^{21}$ Na temat przełamywania stref prywatności (Privatheit) i publicznej (Öffentlichkeit) w kontekście analizowanego z genderowego punktu widzenia podziału władzy zob. m.in. B. Greven-Aschoff, op. cit., s. 22 i n.

22 C. Muysers, Warum gab es berühmte Künstlerinnen. Erfolge bildender Künstlerinnen der zweiten Hälfte des 19. Jahrhunderts, w: Profession ohne Tradition. 125 Jahre Verein der Berliner Künstlerinnen, kat. wyst. Berlinische Galerie, 11 września - 1 listopada 1992, Berlin 1992, s. 21-34; C. Matz, op. cit., s. 25 i n.; K. Stanicka-Brzezicka, op. cit., s. 46 i n.

23 Por. K. Stanicka-Brzezicka, op. cit., rozdz. Działalność Stowarzyszenia Artystek Ślaskich (Vereinigung Schlesischer Künstlerinnen), s. 46-77.

24 C. Matz, op. cit., s. 22. 
Österreichischer Künstlerinnenvereine aller Kunstgattungen GEDOK, 1927) ${ }^{25}$. Działalność kobiecych stowarzyszeń była też wspierana przez miejskie budżety, na przykład w Monachium miasto współfinansowało prowadzoną przez artystki w ramach działalności stowarzyszenia szkołę ${ }^{26}$, miasto Magdeburg udostępniało artystkom miejską halę wystawową (Städtische Kunsthalle) ${ }^{27}$.

Zasadniczą ideą przyświecającą powstawaniu kobiecych organizacji artystycznych była walka z uprzedzeniami i zastrzeżeniami wobec uprawiania sztuki przez kobiety, walka o społeczne uznanie i poprawę warunków pracy oraz o pozycję w świecie artystycznym, „o podstawowe prawo współdecydowania na polu sztuki”28. Artystki walczyły o wprowadzenie zmian w procesie wychowania i wykształcenia, o dostęp kobiet do uczelni artystycznych (ale jednocześnie same organizowały kształcenie w dziedzinie sztuki, tak potrzebne do przezwyciężenia „,narzucanego ze strony państwa i akademii dyletantyzmu"29), o członkostwo w innych organizacjach artystycznych i w jury wystaw. Dążyły do zwiększenia udziału kobiet w dorocznych i akademickich wystawach oraz organizowały własne wystawy połączone ze sprzedażą. Dbały też o zabezpieczenia socjalne dla uprawiających sztukę kobiet. W tym celu zakładały fundusze socjalne, emerytalne, chorobowe, wypadkowe, a także kasy pożyczkowe. Formę wsparcia stanowiły również stypendia i konkursy. Finanse na działalność pochodziły z organizowanych loterii, wystaw i sprzedaży, a także z dotacji państwowych, w tym - jak wspomniano wyżej - miejskich. Nie miały natomiast owe stowarzyszenia żadnego wspólnego programu artystycznego lub tematycznego.

Stowarzyszenie Artystek Śląskich (Vereinigung Schlesischer Künstlerinnen) zawiązane zostało we Wrocławiu 26 stycznia 1902 roku $^{30}$. Jego działalność przez wiele lat pozostawała niemal nieznana i dopiero pod koniec lat 90. ubiegłego wieku stała się przedmiotem zainteresowania autorki, czego wynikiem jest poświęcony mu rozdział w książce Artystki śląskie ok. 1880-1945 ${ }^{31}$. Podjęte wówczas badania opierać się musiały jedynie na skąpych materiałach źródłowych, wśród których na pierwszym miejscu wymienić należy artykuł opublikowany na łamach periodyku „Schlesien. Illustrierte Monatschrifte zur Pflege Heimatlicher Interessen" w 1908 roku $^{32}$.

$\mathrm{Z}$ wrocławskim stowarzyszeniem w początkowej fazie jego działalności związane były takie artystki jak Gertrud Staats, Elise Nees von Eßenbeck, Anna Gritschker-Kunzendorf, Marie Spieler i Dora Seemann. Niestety nie udało się z całą pewnością

25 Ibidem, s. $369 \mathrm{i} \mathrm{n.}$

26 Ibidem, s. 47.

27 Ibidem, s. 90.

28 Ibidem, s. 13.

29 R. Berger, Malerinnen auf dem Weg ins 20. Jahrhundert. Kunstgeschichte als Sozialgeschichte, DuMont, Köln 1982, s. 87.

30 W.O. Dressler, Dresslers Kunsthandbuch, t. 1 (wyd. 10), Halle-S, Berlin 1934, s. 275.

$31 \quad$ K. Stanicka-Brzezicka, op. cit., s. 46-77.

32 C. Buchwald, Die Vereinigung schlesischer Künstlerinnen, „Schlesien. Illustrierte Monatsschrift zur Pflege Heimatlicher Interessen" 2 (1908/1909), s. 545-551. 
stwierdzić, które z nich były założycielkami ugrupowania i kto tworzył pierwszy zarząd $^{33}$. Przewodniczenie organizacji przez Gertrud Staats jest potwierdzone w 1905 roku $^{34}$, co pozwala na ewentualne formułowanie tezy, że ta niewątpliwie największa osobowość artystyczna tego czasu wśród wrocławskich malarek mogła być jego pierwszą przewodniczącą i sprawować tę funkcję do roku 1906, kiedy to zastąpiła ją Elise Nees von Eßenbeck ${ }^{35}$.

Celem stowarzyszenia była ochrona interesów jego członkiń, organizacja wspólnych wystaw i wysyłanie prac na wielkie wystawy. Członkiniami mogły zostać samodzielne artystki, urodzone lub mieszkające na Śląsku, które wzięły udział w co najmniej trzech wielkich wystawach w Monachium, Dreźnie, Berlinie lub Wiedniu, co miało uniemożliwić napływ amatorek do organizacji. Stowarzyszenie nie prowadziło własnej szkoły, ale jego członkinie w swoich prywatnych atelier kształciły uczennice - taką pracownię miały we Wrocławiu Anna Gritschker-Kunzendorf (od 1897 r.) ${ }^{36}$, Marie Spieler ${ }^{37}$, Helene Tüpke-Grande (od 1900 r.), Elise Nees von Eßenbeck $^{38}$ oraz Else Bartsch ${ }^{39}$. Rekonstruowana ze szczątków informacji historia organizacji pozwala także przypuszczać, że stowarzyszenie nie miało własnej siedziby - we wszelkich wykazach widnieje prywatny adres tej artystki, która w danym momencie sprawowała funkcję sekretarza - np. w 1906 roku Anny Gritschker-Kunzendorf (Goethestrasse 61, obecnie ul. Wielka) ${ }^{40}$, wiele lat później - w 1934 roku Johanny Pistorius (Moritzplatz 3, obecnie pl. Wróblewskiego?) ${ }^{41}$. Stowarzyszenie wystawiało, prawdopodobnie od 1904 roku do I wojny światowej corocznie we wrocławskim salonie Lichtenberga. Wzmianki o tych wystawach znalazły się w renomowanym miesięczniku „Die Kunst. Monatshefte für freie und angewandte Kunst”: pierwsza w 1904 roku $^{42}$, kolejna - dwa lata później ${ }^{43}$. Okazjonalnie prace artystek wystawiano też w innych miastach, na przykład na przełomie kwietnia i maja 1908 roku w Domu Związkowym (Vereinshaus) w Jeleniej Górze, która to wystawa odbiła się echem na łamach regionalnej prasy ${ }^{44}$.

33 Por. Stanicka-Brzezicka, op. cit., s. 50-51.

34 „Jahrbuch der bildenden Kunst” 4 (1905), red. W. Schäfer, szp. 74-75.

35 „Jahrbuch der bildenden Kunst” 5 (1906), red. W. Pastor, szp. 85; „Jahrbuch der bildenden Kunst” 6 (1907), szp. 88.

36 „Jahrbuch der bildenden Kunst” 1 (1902), red. M. Martersteig, szp. 102.

37 Nekrolog autorstwa E. Nees von Eßenbeck, 91. „Jahres-Bericht der Schlesischen Gesellschaft für vaterländischen Cultur" (1913), VI Abteilung, s. 35-36.

38 C. Buchwald, op. cit., s. 550.

39 Ibidem, s. 548. Por. K. Stanicka-Brzezicka, op. cit., s. 52.

40 „Jahrbuch der bildenden Kunst” 5 (1906), red. W. Pastor, szp. 85; ,Jahrbuch der bildenden Kunst” 6 (1907), szp. 88.

${ }^{41} \quad$ W.O. Dressler, op. cit., s. 275.

42 „Die Kunst. Monatshefte für freie und angewandte Kunst” 9 (1904), s. 314.

43 „Die Kunst. Monatshefte für freie und angewandte Kunst” 13 (1906), s. 238.

44 M. Westen, Gemälde-Ausstellung der Vereinigung Schlesischer Künstlerinnen, „Schlesische Heimat-Blätter", nr 16 (15.05.1908), s. 370-373; M. Reddestow, Gertrud Staats und die Hirschber- 
Stowarzyszenie Artystek Śląskich było w porównaniu z podobnymi organizacjami na terenie Niemiec strukturą bardzo małą. W 1908 roku liczyło zaledwie 13 członkinn $^{45}$. Po pierwszej wojnie liczba ta wzrosła: w 1927 roku notowane są 24 nazwiska ${ }^{46}$, w $1934-35^{47}$. Przyrost członkiń jeszcze w latach 30. XX wieku był zasadniczo tendencją odwrotną do innych stowarzyszeń tego typu, nie jest także w pełni zrozumiały w kontekście tego, że od lat 20. XX wieku wrocławskie artystki mogły być pełnoprawnymi członkiniami Związku Artystów Śląska (Künstlerbund Schlesien, 1908) i wielu nowych, „młodych” organizacji artystycznych, jak choćby Gruppe 1922. Szczątkowo możemy udokumentować także współpracę stowarzyszenia z innymi organizacjami, na przykład ze Związkiem Śląskich Artystek Włókniarek (Verband Schlesischer Textilkünstlerinnen), założonym na początku XX wieku przez Marthę Langer-Schlaffke, zrzeszającym kobiety zajmujące się malarstwem na tkaninie, tkactwem, techniką batiku, haftem czy koronkarstwem. W 1925 roku w siedzibie Gesellschaft für Vaterländische Kultur miała miejsce wspólna wystawa malarstwa i wyrobów rzemiosła artystycznego ${ }^{48}$.

Mimo niewielu przekazów można zaryzykować stwierdzenie, że Stowarzyszenie Artystek Śląskich wpisało się w krajobraz miasta i regionu. W 1913 roku podkreślano, że jest to ,jedyne wrocławskie stowarzyszenie artystów obok Związku Artystów Śląska, które na szczęście prezentuje się publicznie"49. Jego powstanie było odpowiedzią na organizowanie się artystycznego ruchu kobiecego w Europie i na świecie i konieczność udziału w zinstytucjonalizowanym życiu artystycznym, obejmującym wykształcenie, mecenat i odbiór sztuki w realiach XIX i początku XX wieku. Jednym z najistotniejszych faktów wpisujących śląskie stowarzyszenie w historię kobiecego ruchu artystycznego w Niemczech i nadających mu ponadlokalne znaczenie było członkostwo w założonej w 1908 roku Federacji Niemieckich (i Austriackich) Związków Artystek (Bund deutscher (und österreichischer) Künstlerinnenvereine) $)^{50}$.

ger Ausstellung, „Schlesische Heimat-Blätter”, nr 16 (15.05.1908), s. 383. Więcej na ten temat w: K. Stanicka-Brzezicka, op. cit., s. 53-55.

45 C. Buchwald, op. cit., s. 545.

46 Na podstawie spisu z katalogu wrocławskiej wystawy „Schlesische Wertschau” z 1927 r.

47 W.O. Dressler, op. cit., s. 275. Dla porównania związek berliński w momencie powstania liczył 29 artystek, w 1880 r. - 131, a w 1903 już 315 (plus 524 „Kunstfreundinnen”)! Związek monachijski najwyższą liczbę członkiń osiągnął w latach 1917/1918 - 290. Zob. C. Matz, op. cit., s. 38, 52.

48 A. Schellenberg, Ausstellung für Kunst und Kunstgewerbe, „Schlesische Monatshefte” 2 (1925), nr 5, s. 287.

49 „Schlesisches Jahrbuch” (1913), s. 166.

50 Obok Stowarzyszenia śląskiego zrzeszała: Verein der Künstlerinnen und Kunstfreundinnen zu Berlin, Künstlerinnenverein München, Braunschweigischer Künstlerinnenverein, Bremer Malerinnenverein, Vereinigung der Künstlerinnen Hessen-Nassau, Malerinnen-Sektion des deutschen Vereins Frauenfortschritt z Pragi, Verband Dresdner Künstlerinnen oraz Neue Vereinigung von Künstlerinnen Berlin II. Pomiędzy rokiem 1911 a 1913 do korporacji przystąpiły dwa kolejne stowarzyszenia: Verein der Künstlerinnen und Kunstfreundinnen Magdeburg i Kunstgruppe des Rostocker Frauenvereins. U. Krenzlin, ,, Auf dem ernsten Gebiet der Kunst ernst arbeiten”. Zur Frauenausbildung im künstlerischen Beruf, w: Profession ohne Tradition..., op. cit., s. 73-87, s. 75; C. Matz, op. cit., s. 91. 
Była to organizacja służąca „wzajemnej pomocy i koleżeńskiej wymianie" ${ }^{51}$. Jej celem było „chronić interesy zawodowe czynnych artystek i zjednoczyć niemające wcześniej żadnych wzajemnych kontaktów organizacje artystyczne" ${ }^{92}$. Przewodniczącą korporacji została wrocławianka $\mathrm{z}$ urodzenia, monachijka $\mathrm{z}$ wyboru Martha Giese-Breslau ${ }^{53}$, która od 1904 roku kierowała również monachijskim Künstlerinnenverein. W rozszerzonym zarządzie zasiadała także do roku 1920 przewodnicząca stowarzyszenia wrocławskiego Elise Nees von Eßenbeck ${ }^{54}$. Kolejna wrocławianka Wilhelmine Melzer około roku 1925 lub 1927 została wybrana II przewodniczącą korporacji ${ }^{55}$. Członkostwo w tej naczelnej organizacji było dla tak małych stowarzyszeń jak wrocławskie szczególnie korzystne, zapewniało bowiem łatwy dostęp do informacji i możliwość wymiany doświadczeń. Zasadą działania Bundu było dążenie do przezwyciężenia izolacji kobiecych środowisk artystycznych i udział kobiet w ogólnym współzawodnictwie w dziedzinie sztuki, a tym samym na przykład rezygnacja z organizacji wystaw sztuki wyłącznie kobiecej. Vereinigung Schlesischer Künstlerinnen nie było natomiast później członkiem GEDOK-u, chociaż korporacja ta kilkakrotnie próbowała nawiązać kontakt ze stowarzyszeniem wrocławskim ${ }^{56}$.

Tezą niniejszego wywodu jest usytuowanie powstania i działalności Stowarzyszenia Artystek Śląskich w kontekście procesu formułowania się w środowisku inteligencji mieszczańskiej od drugiej połowy XIX do początków XX wieku kobiecej kultury stowarzyszeniowej, a tym samym próba spojrzenia raz jeszcze na stowarzyszenie przez pryzmat środowiska i klasy społecznej. Takie ujęcie wydaje się uzasadnione nie tylko przez odwołanie się do literatury pisanej z podobnej perspektywy badawczej lub poddającej tę metodologię analizie, ale także przez wyraźny związek kontekstu społecznego czy klasowego z tematyką i stylistyką dzieł. Twórczość artystek związanych z wrocławskim stowarzyszeniem została zasadniczo omówiona w przywoływanej tu kilkakrotnie książce o artystkach śląskich ${ }^{57}$. Już wówczas udało się dostrzec $\mathrm{w}$ ich dziełach spory rys tradycjonalizmu. Uprawiano głównie malarstwo pejzażowe, portretowe, martwych natur i kwiatów. W dużej mierze była to sztuka hołdująca tradycjom mieszczańskim, daleka od żywych już wówczas trendów awangardowych.

W pierwszej kolejności przypomnieć tu należy Marie Spieler, uprawiającą osadzone w tradycji, reprezentacyjne malarstwo portretowe. Jej modelami są często oso-

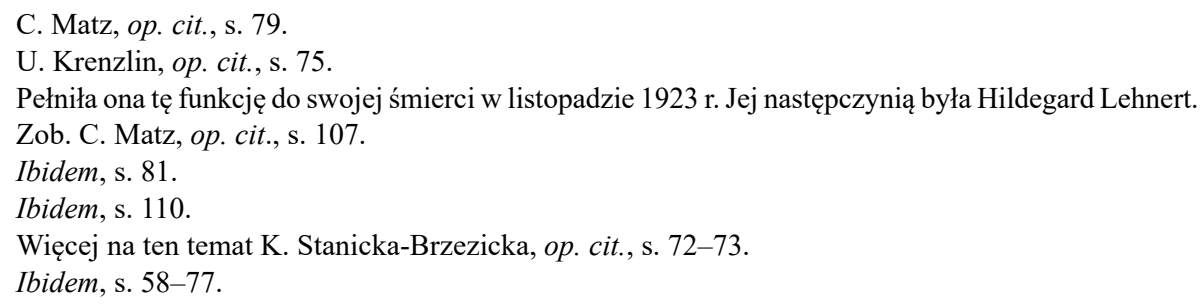


by z wyższych sfer, jak hrabina Carolina von Pückler-Burghaus ${ }^{58}$ czy dzieci rodziny Jerin, których salonowy portret z około 1883 roku w duchu akademickim, o eklektycznych formach, łączy

(...) barokową reprezentacyjność z naturalistycznym oddaniem szczegółów (np. falbanki sukienki dziewczynki), perfekcyjną techniką malarską oraz charakterystyczną dla arystokratycznych portretów wystudiowaną kompozycją z atrybutami: skórą tygrysa, kotarą w tle po lewej stronie i pejzażem à la renaissance po prawej. Mieszczański charakter ma również autoportret malarki z berlińskiej Nationalgalerie ${ }^{59}$.

Jest to portret kobiety, nie artystki. Nie posiada atrybutów określających zawód malarza, widoczna partia ubrania to elegancka bluzka ozdobiona koronką, tło obrazu jest neutralne. Akcent stanowi jasna partia twarzy z wiernie oddanymi rysami i dekolt ze wspomnianą już koronką. Otwarte pozostaje pytanie, dlaczego artystka, konstruując własny wizerunek, nie skorzystała $\mathrm{z}$ akcesoriów i znaków identyfikacji twórcy. Nadinterpretacją byłoby chyba stwierdzenie, że odrzuciła konwencję autoportretu artysty stworzoną przez mężczyzn, ale być może, nawet nieświadomie, dała tym obrazem wyraz przewagi w życiu kobiecego, nieartystycznego doświadczenia i losu ${ }^{60}$.

Portrecistką wytwornego towarzystwa była też Anna Gritschker-Kunzendorf. Na łamach „Schlesische Woche” o artystce i jej pracach pisał w roku 1913 Felix Wilborn:

(...) artystka, która wybija się ponad przeciętny poziom portrecistów (...). Mimo całej pieczołowitości, z którą namalowane zostały obrazy, i która zmusiła artystkę do ciągłego przemalowywania, zdumiewa nas wspaniałe oddanie ciała i materii (...) jakąż szlachetność zawiera wizerunek pani von Goßler, ile artystycznych umiejętności tkwi w pełnym wyrazu portrecie hrabiego von Clary und Aldringen! Jak okazale namalowana jest czarna suknia hrabiny von Ballestrem, z jakąż przyjemnością możemy przypatrywać się wszędzie perłom i kamieniom szlachetnym $^{61}$.

Prostota i szlachetność środków artystycznego wyrazu - oszczędna kompozycja i stonowany walor z jasnymi akcentami twarzy, dłoni, a także kołnierzyków czy mankietów - charakteryzuje też ujęcia Agnes Langenbeck-Zachariae (ur. 1866), na przykład portret męża artystki, i Elisabeth Kranz-Gerhard (1870-1942): Portret pastora Paula Gerharda i Portret pastora Friedricha Siegmunda Schultze ${ }^{62}$.

Osobny rozdział stanowi twórczość Gertrud Staats $(1859-1938)^{63}$. Studia malarskie rozpoczęła ona około połowy lat 70. XIX wieku u Hermanna Bayera, malarza

58 Portret namalowany w $1909 \mathrm{r}$. znany jest z reprodukcji na łamach „Schlesien. Illustrierte Monatschrift zur Pflege Heimatlicher Interessen" 4 (1910/1911), s. 144.

59 1876. Nr inw. A III 360.

${ }_{60}$ K. Stanicka-Brzezicka, op. cit., s. 59-60.

${ }^{61}$ F. Wilborn, Ausstellung von Werken schlesischer Künstler im Schlesischen Kunstverein (A. Lichtenberg), ,Schlesische Woche”, nr 10 (14.09.1913), s. 4-5.

62 Oba 1907, Muzeum Narodowe we Wrocławiu, nr inw. VIII-689 i VIII-695.

${ }_{63}$ Por. K. Stanicka-Brzezicka, ,, Między tradycją a nowoczesnościa”. Twórczość Gertrud Staats, w: eadem, op. cit., s. $78-99$. 
scen rodzajowych i pejzaży. Niedługo później została uczennicą znanego wrocławskiego pejzażysty Adolfa Dresslera, który odcisnął zasadnicze piętno na twórczości młodej malarki ${ }^{64}$. Badacze dopatrują się wpływu mistrza w wyborze romantyczno-idyllicznych motywów pejzażowych, fragmentaryczności ujęcia oraz stosowaniu ciemnych barw kontrastujących z partiami oświetlonymi intensywnym światłem i ciemnych teł, a także w realizmie, dramatyzmie i teatralności. Inni ${ }^{65}$ twierdzą jednak, że prace Staats już od początku różniły się nieco od dzieł nauczyciela: nie ma w nich tej idylliczności Dresslera, jej obrazy są surowsze, natura jawi się bardziej pierwotną, światło zaś jest intensywniejsze, ale i bardziej równomiernie rozłożone. Te tendencje nasiliły się po śmierci Dresslera w 1881 roku i pod wpływem kolejnych nauczycieli, zwłaszcza Carla Covena Schirma, który kierował we Wrocławiu Mistrzowską Pracownią Malarstwa Krajobrazowego przy Muzeum Sztuk Pięknych. Wreszcie kolejnym przełomem było spotkanie z Adolfem Hölzerem w kolonii artystycznej w Dachau i później Ludwikiem Dillem. Ta wychowana w mieszczańskim domu córka kupca i radcy miejskiego, nosząca przez całe życie „kaftany w typie spencer i długie, fałdowane spódnice, wszystko w czerni (...) bardziej niż niestosowne" ${ }^{66}$, przeszła drogę od malarstwa realistycznego w tradycji akademickiej, poprzez impresjonizm, wpływy secesji, do protoekspresjonizmu, i należy do głównych przedstawicieli na Śląsku wywodzącego się z tradycji biedermeierowskich malarstwa plenerowego (Freilichtmalarei).

Sztuka Staats wpisuje się również idealnie w ówczesne realia artystyczne Niemiec, w tamtejszy krajobraz artystyczny, bardzo dynamiczny, z licznymi stylistycznymi i konceptualnymi Interferenzen, łączący równocześnie tradycję (mieszczańską) i eksperyment zwany „Lebensreform”. Poprzez silny element „rodzimości” zainteresowanie dla śląskiego krajobrazu nawiązuje także do ruchu Heimatkunst ${ }^{67}$.

O ile przekazy o działalności Śląskiego Stowarzyszenia Artystek są skąpe, o tyle zupełnie nie jest znany jego koniec. Nie wiadomo dokładnie, jak długo stowarzyszenie działało, czy zostało formalnie rozwiązane. Ostatnie ślady działalności organi-

64 Na ten temat zob. m.in. H. Lossow, Gertrud Staats. Ein Beitrag zur Geschichte der Freilichtmalerei, „Schlesische Heimat. Zeitschrift für Heimat- und Naturschutz” 5 (1940), s. 14-25; E. Scheyer, Gertrud Staats und die Landschaftsmalerei in Schlesien, „Schlesien. Kunst, Wissenschaft, Volkskunde” 25 (1980), z. 2, s. 108-112; K. Stanicka-Brzezicka, op. cit., s. 81-84.

65 Na przykład C. Müller-Hofstede, Schlesische Landschaftskunst vor 30 Jahren. Ausstellung im Schlesischen Museum der Bildenden Künste zu Breslau, „Der Oberschlesier” 21 (1939), nr 1, s. 146-152; L. Hyss, Zwischen Tradition und Moderne. Der künstlerische Werdegang von Gertrud Staats, w: Gertrud Staats 1859 - Breslau - 1938. Eine Malerin zwischen Tradition und Moderne, Haus Schlesien - Museum für Landeskunde Königswinter-Heisterbacherrott, 12 kwietnia - 29 czerwca 1997, Grafschaftsmuseum Wertheim/Main 5 lipca - 7 sierpnia 1997, Königswinter 1997, s. 3-8.

66 H. Gerlinger-Brandes, Erinnerungen an Gertrud Staats, w: Gertrud Staats 1859 - Breslau - 1938..., op. cit., s. 9.

67 K. Stanicka-Brzezicka, op. cit., s. 98. 
zacji przypadają na pierwszą połowę lat 30. Najprawdopodobniej podzieliła ona los wielu podobnych związków, które nie przetrwały rządów narodowego socjalizmu.

Historia stowarzyszenia stanowi uzupełnienie stanu badań nad historią kobiet we Wrocławiu i na Śląsku. Jest „historią dawną”, opowiadającą o realiach, środowisku artystycznym i instytucjach przedwojennego Breslau. Pomimo odniesienia się w nazwie stowarzyszenia do całego regionu bez wątpienia miasto stanowiło centrum jego działalności i dawało zaplecze niezbędne we wspólnym działaniu. Miasto bywało też motywem twórczości (np. Marie Spieler), ale jest to temat na osobne opracowanie. Jednocześnie fakt wywodzenia się stowarzyszenia, przynajmniej w jego początkach, z kręgów mieszczańsko-inteligenckich wpisuje podjęty tu temat w postulat badawczy sformułowany przez Ritę Huber-Sperl ${ }^{68}$, dotyczący roli pochodzenia, przynależności klasowej i konfesji ${ }^{69} \mathrm{~W}$ powstawaniu organizacji kobiecych. Mimo niewielkiej liczby zachowanych źródeł i w związku z tym niemożności pełniejszego opisania jego celów, działań czy powiązań w środowisku widzieć je należy na pewno jako wyraz artystyczno- i polityczno-emancypacyjnego zaangażowania społecznego kobiet i element gęstej sieci organizacji kobiecych rozciągającej się w dziewiętnasto- i dwudziestowiecznych Niemczech od miasta do miasta.

\section{Bibliografia}

Adorno Th.W., Ästhetische Theorie. Gesammelte Schriften, t. 7, Suhrkamp Verlag, Frankfurt [1973], 2003.

Barrow L. i in. (red.), Nichts als Unterdrückung? Geschlecht und Klasse in der englischen Sozialgeschichte, Westfälisches Dampfboot, Münster 1991.

Berger R., Malerinnen auf dem Weg ins 20. Jahrhundert. Kunstgeschichte als Sozialgeschichte, DuMont, Köln 1982.

Beyme K. von, Das Zeitalter der Avantgarden. Kunst und Gesellschaft 1905-1955, C.H. Beck, München 2005.

Buchwald C., Die Vereinigung schlesischer Künstlerinnen, „Schlesien. Illustrierte Monatsschrift zur Pflege Heimatlicher Interessen” 2 (1908/1909), s. 545-551.

„Die Kunst. Monatshefte für freie und angewandte Kunst” 9 (1904), 13 (1906).

Dressler W.O., Dresslers Kunsthandbuch, t. 1 (wyd. 10), Halle-S, Berlin 1934.

Filmer W., 90 Jahre: Marg Moll, „Der Wegweiser” 26 (1974), z. 6/7, s. 17-21.

Fischer J., Delitz H. (red.), Die Architektur der Gesellschaft. Theorien für die Architektursoziologie, Transcript, Bielefeld 2009.

68 R. Huber-Sperl, Einleitung, w: Organisiert und engagiert..., op. cit., s. 23.

${ }_{69}$ Pytanie o tę kwestię zapewne warto by zadać także w odniesieniu do środowiska wrocławskiego przełomu XIX i XX wieku, zwłaszcza wobec faktu opublikowania w ostatnich latach wyników badań nad udziałem środowisk żydowskich w artystycznym i kulturalnym życiu miasta. Zob. M. Stolarska-Fronia, Udziat środowisk Żydów wrocławskich w artystycznym $i$ kulturalnym życiu miasta od emancypacji do 1933 roku, Wydawnictwo Neriton, Warszawa 2008, tu zwłaszcza podrozdział poświęcony malarce Clarze Sachs, s. 249-251. 
Frank S., ,, The beautiful source of suburban womanhood!”. Die Architektur der Gesellschaft aus Sicht der Gender Studies, w: J. Fischer, H. Delitz (red.), Die Architektur der Gesellschaft. Theorien für die Architektursoziologie, Transcript, Bielefeld 2009, s. 253-288.

Gerlinger-Brandes H., Erinnerungen an Gertrud Staats, w: Gertrud Staats 1859 - Breslau 1938. Eine Malerin zwischen Tradition und Moderne, Haus Schlesien - Museum für Landeskunde Königswinter-Heisterbacherrott, 12 kwietnia - 29 czerwca 1997, Grafschaftsmuseum Wertheim/Main, 5 lipca - 7 sierpnia, Königswinter 1997.

Gertrud Staats 1859 - Breslau - 1938. Eine Malerin zwischen Tradition und Moderne, Haus Schlesien - Museum für Landeskunde Königswinter-Heisterbacherrott, 12 kwietnia - 29 czerwca 1997, Grafschaftsmuseum Wertheim/Main, 5 lipca - 7 sierpnia 1997, Königswinter 1997.

Greven-Aschoff B., Die bürgerliche Frauenbewegung in Deutschland 1894-1933, Vandenhoeck \& Ruprecht, Göttingen 1981.

Heuschen G., Nützlich, gesellig, tugendsam - der bürgerliche Mann um 1800, w: K.H. Schneider (red.), Geschlechtsrollen in der Geschichte aus polnischer und deutscher Sicht, LIT Verlag, Münster 2004, s. 159-178.

Huber-Sperl R., Bürgerliche Frauenvereine in Deutschland im ,,langen” 19. Jahrhunderteine Überblickskizze (1780-1910), w: R. Huber-Sperl, K. Wolff (red.), Organisiert und engagiert. Vereinskultur bürgerlicher Frauen im 19. Jahrhundert in Westeuropa und den USA, Ulrike Helmer Verlag, Königstein 2002, s. 41-47.

Huber-Sperl R., ,, Wie ein Damoklesschwert” - Vereinsrecht und bürgerliche Frauenbewegung an der Wende zum 20. Jahrhundert, w: K.H. Schneider (red.), Geschlechtsrollen in der Geschichte aus polnischer und deutscher Sicht, LIT Verlag, Münster 2004, s. 195-214.

Huber-Sperl R., Wolff K. (red.), Organisiert und engagiert. Vereinskultur bürgerlicher Frauen im 19. Jahrhundert in Westeuropa und den USA, Fennei \& Walz, Königstein 2002.

Hyss L., Zwischen Tradition und Moderne. Der künstlerische Werdegang von Gertrud Staats, w: Gertrud Staats 1859 - Breslau - 1938. Eine Malerin zwischen Tradition und Moderne, Haus Schlesien - Museum für Landeskunde Königswinter-Heisterbacherrott, 12 kwietnia - 29 czerwca 1997, Grafschaftsmuseum Wertheim/Main, 5 lipca - 7 sierpnia 1997, Königswinter 1997.

„Jahrbuch der bildenden Kunst” 1 (1902), 4 (1905), 5 (1906), 6 (1907).

„Jahres-Bericht der Schlesischen Gesellschaft für vaterländischen Cultur” (1913), VI Abteilung.

Kerchner B., Beruf und Geschlecht. Frauenverbände in Deutschland 1848-1908, Vandenhoeck \& Ruprecht, Vandenhoeck \& Ruprecht, Göttingen 1992.

Klute-Heidemann E., Erinnerungen einer Kunstschülerin 1903 bis 1918. Breslau-DresdenWeimar-Berlin, Verlag am Schlössen, Kaufungen 1991.

Kock J., Frey M. (red.), Bürgerkultur und Mäzenatentum im 19. Jahrhundert, Fennei \& Walz, Berlin 1998.

Krenzlin U., ,Auf dem ernsten Gebiet der Kunst ernst arbeiten”. Zur Frauenausbildung im künstlerischen Beruf, w: Profession ohne Tradition. 125 Jahre Verein der Berliner Künstlerinnen, kat. wyst. Berlinische Galerie, 11 września - 1 listopada 1992, Berlin 1992, s. $73-87$.

Lossow H., Gertrud Staats. Ein Beitrag zur Geschichte der Freilichtmalerei, „Schlesische Heimat. Zeitschrift für Heimat- und Naturschutz" 5 (1940), s. 14-25. 
Matz C., Die Organisationsgeschichte der Künstlerinnen in Deutschland von 1867 bis 1933, dysertacja doktorska, Fakultät für Kulturwissenschaften der Eberhard-Karls-Universität, Tübingen 2000, http://w210.ub.uni-tuebingen.de/dbt/volltexte/2001/417 (2002) (dostęp: 3.03.2016).

Müller-Hofstede C., Schlesische Landschaftskunst vor 30 Jahren. Ausstellung im Schlesischen Museum der Bildenden Künste zu Breslau, „Der Oberschlesier” 21 (1939), nr 1, s. 146-152.

Muysers C., Warum gab es berühmte Künstlerinnen. Erfolge bildender Künstlerinnen der zweiten Hälfte des 19. Jahrhunderts, w: Profession ohne Tradition. 125 Jahre Verein der Berliner Künstlerinnen, kat. wyst. Berlinische Galerie, 11 września - 1 listopada 1992, Berlin 1992.

Nowosielska-Sobel J., Od ziemi rodzinnej ku ojczyźnie ideologicznej. Ruch ochrony stron ojczystych (Heimatschutz) ze szczególnym uwzględnieniem Śląska (1871-1933), Acta Universitatis Wratislaviensis, nr 3491, Wydawnictwo Uniwersytetu Wrocławskiego, Wrocław 2013.

Reddestow M., Gertrud Staats und die Hirschberger Ausstellung, ,Schlesische Heimat-Blätter", nr 16 (15.05.1908).

Schellenberg A., Ausstellung für Kunst und Kunstgewerbe, „Schlesische Monatshefte" 2 (1925), $\mathrm{nr} 5$.

Scheyer E., Gertrud Staats und die Landschaftsmalerei in Schlesien, „Schlesien. Kunst, Wissenschaft, Volkskunde" 25 (1980), z. 2, s. 108-112.

„Schlesien. Illustrierte Monatschrift zur Pflege Heimatlicher Interessen” 4 (1910/11).

„Schlesisches Jahrbuch” (1913).

Schneider K.H. (red.), Geschlechtsrollen in der Geschichte aus polnischer und deutscher Sicht, seria: Politik und Geschichte, t. 5, red. A. von Saldern, H. Bley, H.H. Nolte, Historisches Seminar der Universität Hannover, LIT Verlag, Münster 2004.

Stanicka-Brzezicka K., Artystki śląskie ok. 1880-1945, Wydawnictwo Adam Marszałek, Toruń 2006.

Stolarska-Fronia M., Udziat środowisk Żydów wrocławskich $w$ artystycznym $i$ kulturalnym życiu miasta od emancypacji do 1933 roku, Wydawnictwo Neriton, Warszawa 2008.

Westen M., Gemälde-Ausstellung der Vereinigung Schlesischer Künstlerinnen, „Schlesische Heimat-Blätter", nr 16 (15.05.1908), s. 370-373.

Wilborn F., Ausstellung von Werken schlesischer Künstler im Schlesischen Kunstverein (A. Lichtenberg), „Schlesische Woche”, nr 10 (14.09.1913). 